\title{
The Effect of Human Capital, Total Assets, Total Liabilities on the Net Income of a Company
}

DOI: https://doi.org/10.47175/rissj.v1i3.229

\section{| Surbakti Karo-Karo ${ }^{1}$ | Jihen Ginting ${ }^{2}$ |}

\author{
1,2 Accounting Study Program, \\ Universitas Negeri Medan, \\ Indonesia \\ ${ }^{1}$ surbakti.karokaro@unimed.ac.id. \\ 2 jihenginting@unimed.ac.id
}

\begin{abstract}
The problem in this study is that every company wants low costs and high profits for the company, every employee wants a high salary/wages for payment of performance, also how much influence the assets and debts of the company in providing net profit for the company. This study aims to determine the effect of Human Capital, Total Assets and Total Liabilities on the company's Net Profit in companies listed on the Indonesia Stock Exchange LQ45 index. The sampling method used was purposive sampling, with a total sample of 27 companies, for 2017-2018 there were 54 samples. The results show that Human Capital, Total Liabilities and Total Assets simultaneously have a significant effect on company net income.

KEYWORDS

Human Capital; Total Aset; Total Liabilities; Net Income; Index LQ-45
\end{abstract}

\section{INTRODUCTION}

The main goal of each company is not only profit maximization, but also the welfare of every driving component of the company (Waheed, 2012). But to maintain its business, a company needs a profit that can support all its needs, profit is important for every company, especially for a profit-based company, because by generating profits, the company can sustain its life from year to year following the development of the existing economy. Net income is important for the company because with net income, there is a possibility that the company can develop its business for the better (Lusi \& Nurma, 2015). By tracking net income from time to time or comparing changes in the components of income and expenses to net income, it can be seen that the success of the company's operations in a certain period. Human resources (human capital) plays an important role in the running of a company. Because in the company, human resources (human capital) will become

The company's driving system or in other words, the company's performance system. The role of humans as a company's human capital is very important in influencing the company's net income (Akinlow and Olayiwola, 2017). Humans are the most important asset in an organization, both large and small organizations (Susiawan and Muhid, 2015). Companies cannot maximize profits without competent and dedicated human resources to company goals (Fauziah, et al, 2013). The loss or transfer of professional human resources for a company is a big loss because it will throw away the costs that have been incurred by the company to foster or educate the human resources it has acquired.

Every company wants its company to grow bigger from time to time, because with a bigger company, the possibility of the company to get more profit will increase. Apart from human capital, of course other factors also play a role in the company's net profit, namely assets. If you use a simple analogy, it can be seen that the greater the assets we have, the greater the production we can produce, the greater the production, the greater our chances of making a profit even though it will be reduced by the expenses that exist to 
make a net income. Due to the existence of large assets, something that the company uses in trying to get a profit will be even greater.

Asian Umobong's research (2015) found that debt affects the growth of company profits, with the growth of company profits, there is an opportunity to maximize the company's net profit. Companies that have gone public definitely need additional funds or capital for their operational activities. In this study, the variable used is debt. According to Herispon, to get funds, it can be through external sources, such as debt. Debt is all the company's financial obligations to other parties that have not been fulfilled where this debt is a source of funds or company capital that comes from creditors (Herispon, 2016). With corporate debt, you can buy assets or anything that can be used by the company to create profits for the company. the.

This research is a replication of research by Olayinka Akinlo \& and John Olayiwola (2017) entitled "human capital reporting and corporate earnings: evidence from Nigeria". The difference between this study and previous research is that this study does not use the share prices variable, the indicators used for the human capital variable are salaries and wages only, population and research samples, company data sources.

\section{RESEARCH METHODS}

This research is quantitative, the research was conducted on the financial statements of companies in IHSG which are listed in the LQ-45 index for 2017-2018. There was a sample of 32 companies after being selected with various criteria, then analyzed using SPSS in multiple linear regression analysis.

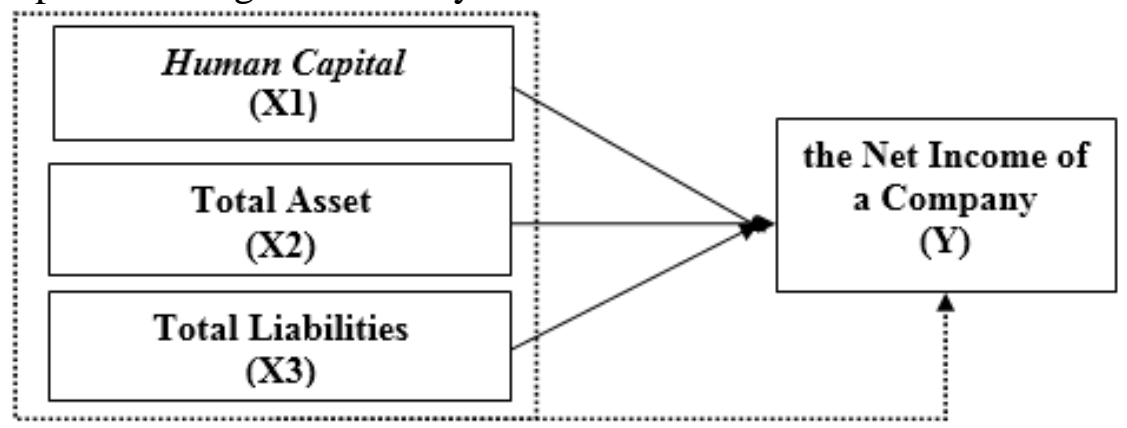

Figure 1. Framework Thinking

Here are the sampling method based on the aims and objectives of the study with the following criteria:

1. Companies listed on the LQ-45 Index and remain in the Index during the 2017-2018 period on the Indonesia Stock Exchange.

2. Companies that publish their salaries and wages data for 2017-2018

3. Companies that have net income during 2017-2018.

4. Companies in the LQ-45 Index that are not identified as Outliers.

The equations for testing the overall hypothesis in this study are as follows:

$\begin{array}{clll}\mathrm{Y}=\beta_{0}+\beta_{1} X_{1}+\beta_{2} X_{2}+\beta_{3} X_{3}+e & \\ \text { Where } \quad \mathrm{Y} & =\text { Net Income } \\ & \beta_{0} & \text { Constant } \\ & \beta_{1}, \beta_{2,} \beta_{3} & =\text { Coefficient of Each Variable } \\ X_{1} & =\text { Human Capital } \\ X_{2} & =\text { Total Aset } \\ X_{3} & =\text { Total Liabilities }\end{array}$




\section{RESULTS AND DISCUSSION}

The sample of this study is a company registered in LQ-45 and fulfills the criteria in this study. The following is a table for determining the sample according to the specified criteria:

Table 1. Sample Determination

\begin{tabular}{|c|l|c|}
\hline No. & Sample Criteria & Accumulation \\
\hline 1. & Companies listed on the LQ index - 45 & 45 \\
\hline 2. & $\begin{array}{l}\text { Companies listed on the LQ45 Index and remain in the Index during the } \\
\text { 2017-2018 period on the Indonesia Stock Exchange. }\end{array}$ & 35 \\
\hline 3. & Companies that publish data on salaries and wages for 2017 - 2018 & 33 \\
\hline 4. & Companies that have net income during 2017 - 2018. & 32 \\
\hline \multicolumn{2}{|l}{ The number of research samples that meet the requirements } & $\mathbf{3 2}$ \\
\hline
\end{tabular}

The table above explains that 32 companies were selected as research samples after undergoing a selection process based on predetermined criteria. There were 32 companies out of 45 companies that were still listed on the LQ-45 Index during that year, then there were 2 companies that did not publish annual reports consistently and clearly in the 20172018 period on the Indonesia Stock Exchange, so the salaries and wages data of these companies did not It can be seen, there is 1 company that experienced negative net profit during the 2017-2018 period. Furthermore, there are 32 companies left after making the selection.

Table 2. Descriptive statistical test results

\begin{tabular}{|ll|l|l|l|l|}
\hline \multicolumn{2}{|l|}{ Descriptive } & Statistics \\
\hline & $\mathrm{N}$ & Minimum & Maximum & Mean & Std. Deviation \\
\hline HCC & 54 & Rp342.524.001.000 & Rp16.322.769.000.000 & Rp2.701.518.563.403 & Rp3.305.793.973.247 \\
TL & 54 & Rp980.414.618.000 & Rp1.017.291.789.000.000 & Rp92.515.148.126.123 & Rp218.171.839.589.899 \\
TA & 54 & Rp5.036.396.000.000 & Rp1.202.252.094.000.000 & Rp132.206.661.230.616 & Rp254.491.011.703.830 \\
$\begin{array}{l}\text { TE } \\
\begin{array}{l}\text { Valid N } \\
\text { (listwise) }\end{array}\end{array}$ & 54 & Rp311.874.960.000 & Rp34.995.000.000.000 & Rp7.514.681.578.370 & Rp8.523.271.257.799 \\
\hline
\end{tabular}

Based on the table above, it be can known that:

1. The first independent variable, Human Capital, has the smallest (minimum) value of IDR 342,524,001,000, and the largest (maximum) value of IDR 16,322,769,000,000, with a mean (average) value of IDR 2,701,518,563. standard deviation of IDR $3,305,793,973,247$

2. The second independent variable, Total Liabilities, has the smallest (minimum) value of IDR 980,414,618,000, the largest value (maximum) IDR 1,017,291,789,000,000 mean (average) value IDR 92,515,148,126,123 and a standard deviation (standard deviation) Rp218,171,839,589,899.

3. The third independent variable, namely Total Assets, has the smallest (minimum) value of Rp5,036,396,000,000, the largest (maximum) value of Rp1,202,252,094,000,000 mean (average) value of Rp.132,206,661,230,616 and a standard deviation (standard deviation) Rp254,491,011,703,830.

4. The dependent variable, namely Net Income (Total Earning) has the smallest (minimum) value of IDR 311,874,960,000, the largest (maximum) value of IDR $34,995,000,000,000$, the mean (average) value of IDR 7,514,681,578,370 and a standard deviation (standard deviation) amounting to Rp8,523,271,257,799. 
Table 3. Normality Test Results

\begin{tabular}{|l|l|l|}
\hline \multicolumn{2}{|c|}{ One-Sample Kolmogorov-Smirnov Test } \\
\hline \multicolumn{2}{|c|}{ N } & Unstandardized Residual \\
\hline \multirow{2}{*}{ Normal Parameters ${ }^{\mathrm{a}, \mathrm{b}}$} & Mean & 54 \\
\cline { 2 - 3 } & Std. Deviation & $-23197361838,9142800$ \\
\hline \multirow{3}{*}{ Most Extreme Differences } & Absolute &, 095 \\
\cline { 2 - 3 } & Positive &, 095 \\
\cline { 2 - 3 } & Negative &,- 088 \\
\hline Test Statistic &, 095 \\
\hline Asymp. Sig. (2-tailed) &, $200^{c, d}$ \\
\hline a. Test distribution is Normal. \\
\hline b. Calculated from data. \\
\hline c. Lilliefors Significance Correction. \\
\hline d. This is a lower bound of the true significance. \\
\hline
\end{tabular}

The table above shows a significance value greater than 0.05 . it can be seen that the significance value (Asymp, Sig 2-tailed) is 0.085 .

Table 4. Multicollinearity test

\begin{tabular}{|c|c|c|c|c|c|c|}
\hline \multicolumn{7}{|c|}{ Coefficients $^{\mathbf{a}}$} \\
\hline & \multirow{2}{*}{ Model } & \multicolumn{2}{|c|}{ Unstandardized Coefficients } & \multirow{2}{*}{$\begin{array}{l}\text { Standardized } \\
\text { Coefficients } \\
\text { Beta }\end{array}$} & \multicolumn{2}{|l|}{$\begin{array}{l}\text { Collinearity } \\
\text { Statistics }\end{array}$} \\
\hline & & B & Std. Error & & Tolerance & VIF \\
\hline \multirow[t]{4}{*}{1} & (Constant) & $-1063548834310,600$ & 730625809598,563 & & & \\
\hline & $\mathrm{HCC}$ & 1,491 & 0,331 & 0,578 & 0,177 & 5,657 \\
\hline & TL & $-0,183$ & 0,020 & $-4,672$ & 0,011 & 89,127 \\
\hline & TA & 0,162 & 0,018 & 4,841 & 0,010 & 98,447 \\
\hline
\end{tabular}

Based on the table above shows the Tolerance and VIF HCC (Human Capital) values of 0.177 and 5.567, the Tolerance and VIF TL (Total Liabilities) values of 0.011 and 89.127, then the Tolerance and VIF TA (Total Assets) values of 0.010 and 98.447.

Table 5. Autocorrelation Test

\begin{tabular}{|l|l|}
\hline \multicolumn{1}{|c|}{ Runs Test } \\
& $\begin{array}{l}\text { Unstandardized } \\
\text { Residual }\end{array}$ \\
\hline Test Value & 341448252549,62085 \\
\hline Cases $<$ Test Value & 27 \\
\hline Cases $>=$ Test Value & 27 \\
\hline Total Cases & 54 \\
\hline Number of Runs & 21 \\
\hline Z & $-1,923$ \\
\hline Asymp. Sig. (2-tailed) &, 054 \\
\hline a. Median \\
\hline
\end{tabular}

Based on the table aboive, it can be concluded that the residual is random or there is no autocorrelation between residual values because the significance exceeds $\alpha=0.05$. 
Table 6. Heteroscedasticity Test Results

\begin{tabular}{|c|c|c|c|c|c|c|}
\hline \multicolumn{7}{|c|}{ Coefficients $^{\mathrm{a}}$} \\
\hline \multirow{2}{*}{ Model } & & \multicolumn{2}{|c|}{ Unstandardized Coefficients } & \multirow{2}{*}{$\begin{array}{l}\text { Standardized } \\
\text { Coefficients } \\
\text { Beta }\end{array}$} & \multirow{2}{*}{$\mathrm{t}$} & \multirow{2}{*}{ Sig. } \\
\hline & & $\mathrm{B}$ & Std. Error & & & \\
\hline \multirow[t]{4}{*}{1} & (Constant) & 1635482816628,125 & \multicolumn{2}{|l|}{441231483899,560} & 3,707 & ,001 \\
\hline & $\mathrm{HCC}$ & ,396 & ,200 & 624 & 1,984 & 053 \\
\hline & $\mathrm{TL}$ &,- 019 & 012 & $-1,951$ & $-1,563$ &, 124 \\
\hline & TA & ,011 & ,011 & 1,366 & 1,041 & ,303 \\
\hline
\end{tabular}

It is known that all independent variables (HCC, TL and TA) have a Sig level above 0.05. In the regression model there is no heteroscedasticity problem.

Table 7. Heteroscedasticity Test Results

\begin{tabular}{|c|c|c|c|c|c|c|}
\hline \multicolumn{7}{|c|}{ Coefficients $^{\mathbf{a}}$} \\
\hline \multirow[t]{2}{*}{ Model } & & \multicolumn{2}{|c|}{ Unstandardized Coefficients } & \multirow{2}{*}{$\begin{array}{l}\text { Standardized } \\
\text { Coefficients } \\
\text { Beta }\end{array}$} & \multirow{2}{*}{$\mathrm{t}$} & \multirow[t]{2}{*}{ Sig. } \\
\hline & & $\mathrm{B}$ & Std. Error & & & \\
\hline \multirow[t]{4}{*}{1} & (Constant) & $-1063548834310,604$ & 730625809598,563 & & $-1,456$ & ,152 \\
\hline & $\mathrm{HCC}$ & 1,491 & ,331 & ,578 & 4,509 & ,000 \\
\hline & TL &,- 183 & ,020 & $-4,672$ & $-9,175$ & ,000 \\
\hline & TA &, 162 & 018 & 4,841 & 9,046 & 000 \\
\hline
\end{tabular}

From the multiple linear regression analysis table above, it can be seen that the regression equation model formula is as follows:

$\mathrm{TE}=(-1,063,548,834,310,604)+1,491 \mathrm{HCC}+(-0,183) \mathrm{TL}+0.162 \mathrm{TA}+\mathrm{e}$

Table 8. Determination Coefficient Test Results

\begin{tabular}{|lllll|}
\hline Model & R & R Square & Adjusted R Square & Std. Error of the Estimate \\
\hline 1 &, $924^{\text {a }}$ &, 855 &, 846 & 3346562654015,45850 \\
\hline \multicolumn{2}{|l}{$\begin{array}{l}\text { a. Predictors: (Constant), TA, HCC, TL } \\
\text { b. Dependent Variable: TE }\end{array}$} \\
\hline
\end{tabular}

The calculated R2 coefficient (coefficient of determination) is 0.846 (84.6\%). This magnitude indicates the effectiveness of the regression line obtained in explaining variations in the dependent variable on Net Income (TE). These results can be concluded that the ability of the independent variable Human Capital (HCC), Total Liabilities (TL) and Total Assets (TA) affects Net Profit (TE) by 84.6\%.

Table 9. Results of the Significance Test of Individual Parameters ( $t$ test)

\begin{tabular}{|c|c|c|c|c|c|c|}
\hline \multicolumn{7}{|c|}{ Coefficients $^{\mathbf{a}}$} \\
\hline \multirow{2}{*}{\multicolumn{2}{|c|}{ Model }} & \multicolumn{2}{|c|}{ Unstandardized Coefficients } & \multirow{2}{*}{$\begin{array}{l}\text { Standardized } \\
\text { Coefficients } \\
\text { Beta }\end{array}$} & \multirow{2}{*}{$\mathrm{t}$} & \multirow{2}{*}{ Sig. } \\
\hline & & B & Std. Error & & & \\
\hline \multirow[t]{3}{*}{1} & (Constant) & $-1063548834310,604$ & 73062580 & & $-1,456$ & , 152 \\
\hline & $\mathrm{HCC}$ & 1,491 &, 331 & ,578 & 4,509 & 000 \\
\hline & TL &,- 183 & ,020 & $-4,672$ & $-9,175$ & ,000 \\
\hline
\end{tabular}




\begin{tabular}{|c|l|l|l|l|}
\hline TA $\quad 162$ &, 018 & 4,841 & 9,046 &, 000 \\
\hline a. Dependent Variable: TE & \multicolumn{4}{|l}{} \\
\hline
\end{tabular}

It is found that the Sig value of the HCC variable is 0,000. It means Human Capital has a significant effect on the dependent variable Net Income.

Based on the hypothesis test of the effect of Total Liabilities (TL) (X2) on Net Income (TE) (Y), it is found that the Sig value of TL is 0,000 . If the significance value $<0.05$. It means that partially the independent variable Total Liabilities has a significant effect on the dependent variable Net Income.

Based on the hypothesis test of the effect of Total Assets (TA) (X3) on Net Profit (TE) (Y), it is found that the Sig value of the variable TA is 0,000. It means that Total Assets has a significant effect on the dependent variable Net Income.

Table 10. Simultaneous Significance Test (F Statistical Test)

\begin{tabular}{|c|c|c|c|c|c|c|}
\hline Model & & Sum of Squares & df & Mean Square & $\mathrm{F}$ & Sig. \\
\hline 1 & Regression & $\begin{array}{l}32902720256404660000 \\
00000000,000\end{array}$ & 3 & $\begin{array}{l}109675734188015530000 \\
0000000,000\end{array}$ & 97,929 &, $000^{\mathrm{b}}$ \\
\hline & Residual & $\begin{array}{l}55997407986254950000 \\
0000000,000\end{array}$ & 50 & $\begin{array}{l}111994815972509900000 \\
00000,000\end{array}$ & & \\
\hline & Total & $\begin{array}{l}38502461055030155000 \\
00000000,000\end{array}$ & 53 & & & \\
\hline
\end{tabular}

Dependent Variable: TE

b. Predictors: (Constant), TA, HCC, TL

The table shows that the sig value is 0,000 or less than 0.005 . If the significance value $<0.05$. It means that the independent variable simultaneously has a significant effect on the dependent variable.

\section{Discussion}

\section{The Effect of Human Capital (HCC) (X1) on Net Income (TE)}

Hypothesis 1 test, the test results show the regression coefficient value of the Human Capital variable (HCC) of 1.491 where this identifies that if there is an increase and decrease in the value of the Human Capital variable (HCC), then the value of Net Profit (TE) will increase or decrease by 1.491 with other variable assumptions remain. This means that if the value of the Human Capital (HCC) variable increases by 1 , then Net Profit (TE) will increase by 1.491 and vice versa if the value of the Human Capital (HCC) variable decreases by 1 , then Net Profit (TE) will decrease by 1.491.

Based on the hypothesis test of the effect of Human Capital (HCC) (X1) on Net Profit (TE) (Y), it was found that the Sig value of the HCC variable was 0,000. meaning that H1 is accepted, it can be concluded that the Human Capital (HCC) (X1) variable has a significant effect on Net Income. The results of this study are in line with the research of Akinlow Olayiowola (2017) which states that Human Capital with indicators of salaries and wages has a significant effect on company net income.

Based on the results of the study, it shows that Human Capital has a positive regression coefficient value on Net Income, the condition of Human Capital is considered to be one of the causes of increased profits, so the higher the salary and wages given by the company, the higher the net profit that will be received by the company.

\section{The Effect of Total Liabilities (TL) (X2) on Net Profit (TE)}

Hypothesis test 2, the test results show the value of the Total Liabilities (TL) variable regression coefficient of -0.183 where it identifies that if there is an increase and decrease 
in the value of the Total Liabilities (TL) variable, then the value of Net Profit (TE) will increase or decrease by -0.183 assuming the other variables are fixed. This means that if the value of the Total Liabilities (TL) variable increases by 1, then Net Profit (TE) will decrease by -0.183 and vice versa if the value of the Total Liabilities (TL) variable decreases by 1 , then Net Profit (TE) will increase by -0.183 .

The results of this study are not in line with research conducted by $\mathrm{Hu}$ Vera Handayani and Mayasari (2018). This is probably due to differences in the research sample, because the research of Vera Handayani and Mayasari (2018) only examined one company.

Total Liabilities has a negative regression coefficient value on Net Income, meaning that Total Liabilities has a negative relationship with net income, the condition of Total Liabilities is considered as one of the causes for the ups and downs of net income, so the higher the debt the company has, the lower it is net income to be received by the company.

\section{Effect of Total Assets (TA) (X3) on Net Income (TE)}

Hypothesis 3 test, the test results show that the regression coefficient value of the Total Assets (TA) variable is 0.162 where this identifies that if there is an increase and decrease in the value of the Total Assets (TA) variable, then the value of Net Profit (TE) will increase or decrease by 0.162 with other variable assumptions remain. This means that if the value of the Total Assets (TA) variable increases by 1, then Net Profit (TE) will decrease by 0.162 and vice versa if the value of the Total Liabilities (TL) variable decreases by 1 , then Net Profit (TE) will increase by 0.162 .

Total assets have a positive regression coefficient value on net income, meaning that total assets have a positive relationship with net income, the condition of total assets is considered as one of the causes for the ups and downs of net income, so the higher the assets owned by the company, the higher it is. net income to be received by the company.

\section{The effect of Human Capital (HCC) (X1), Total Liabilities (TL) (X2) and Total Assets (TA)} (X3) on Net Income (TE)

In testing hypothesis 3 simultaneously it can be seen that the significance level is 0.000 , It means that the Human Capital (HCC), Total Liabilities (TL) and Total Assets (TA) variables have a simultaneous (joint) effect on the Company's Net Profit (TE). From the simultaneous significance test (Test F), it can be seen that when the company has more and more assets, higher employee salaries and less debt, the company's Net Profit will increase. Companies that have a lot of total assets can carry out more production activities, because their production activities are more so that the profits that the company will get will be more and more, then the driving force of a company is its human resources, when human resources are in the company. given a good feedback in the form of high salaries and wages, it will likely encourage the morale of the company workers so that it can cause the company's net profit to increase. Then the company that has less debt, the greater the net profit that the company will get because the costs incurred by the company in that period will be less if the company's debt is small.

\section{CONCLUSION}

Human Capital has a significant positive effect on the net income of a company. This proves that in line with Agency theory, namely the principal wants good results and the agent also wants something good for the business he does.

Total Liabilities of a company have a significant negative effect on the Company's Net Profits. This proves that the amount of debt can increase Net Income. This increase was 
due to the reduction in company debt which could make the company spend less in that period so that its net profit would increase.

Total company assets have positive effect on company net income. This proves that the more assets the company has, the more net profit the company generates, because with more assets, the company can produce more and more, thereby increasing the company's net profit.

Human Capital, Total Liabilities and Total Assets simultaneously have a significant effect on company net income. It can be concluded that when the company has higher assets, higher company salaries and lower debt, the company's net profit will increase.

\section{REFERENCES}

Agustina Indriyani. (2014). Analisis Pengaruh Gaji Dan Tunjangan Kesejahteraan Terhadap Produktivitas Kerja Karyawan Operation Department PT. Export Leaf Indonesia. ISSN :1693-0827 Universitas Islam Batik Surakarta.

Akinlo, Olayiowola. ((2017). Human Capital Reporting and Corporate Earnings: Evidence From Nigeria Tahun 2007-2014. Jurnal The IBRF V 11, No. 1, 2017, pp. 77-85 ol

Anton, F. (2010). Menuju Teori Stewardship Manajemen. Majalah Ilmiah INFORMATIKA, Vol. 1 No. 2.

Asian Umobong. (2015). Assessing The Impact Of Liquidity And Profitability Ratios On Growth Of Profits In Pharmaceutical Firms In Nigeria. European Journal of Accounting, Auditing and Finance Research Vol.3, No.10, pp.97-114, October 2015.

Dwi Martini, Dkk (2017). Akuntansi keuangan menengah berbasis PSAK (buku 1),Jakarta: Salemba Empat 2017 - Cetakan ke-3

Edom, Inah \& Adanma. (2015). The Impact Of Human Resource Accounting on The Profitability of A Firm: Empirical Evidence From Access Bank of Nigeria Plc. European Journal of Accounting, Auditing and Finance Research Vol.3, No.7, pp.7290, July 2015.

Erni Astuti. (2018). Pengaruh Total Hutang Dan Modal Kerja Terhadap Laba pada perusahaan yang terdaftar di Bursa Efek Indonesia tahun 2015-2017. Skripsi: Fakultas Ekonomi dan Bisnis Universitas Muhammadiyah Sumatera Utara 2018

Faujiah, Aspahani \& Yuniarti. (2013). Analisis Penerapan Akuntasi Sumber Daya Manusia Pada Rsup Dr. Mohammad Hoesin Palembang. jurnal penelitian dan pengembangan akuntansi Vol.7 No.2 Juli 2013

Ghozali, Imam. (2012). Aplikasi Analisis Multivariate dengan Program IBM SPSS. Yogyakarta: Universitas Diponegoro

Hanna Tamara Putri. (2018). Pengaruh Total Persediaan, Total Aktiva dan Total Modal terhadap Laba Bersih pada Sub Sektor Properti dan Real Estate yang Terdaftar di Bursa Efek Indonesia (BEI) Periode 2012-2016. Jurnal, Ekonomis: Journal of Economics and Business Vol.2 No.2 September 2018

Hadi Nor. (2011). Corporate Social Responsibility. Yogyakarta: Graha Ilmu

Hendry Adam. (2015). Accounting Principle. Modul Pembelajaran: Universitas Kebangsaaan

Herispon SE, M.Si. (2016). Analisis Laporan Keuangan (Financial Statement Analysis) Buku Ajar. Akademi Keuangan \& Perbankan Riau (Akbar) Pekanbaru

Herispon SE, M.Si. (2018). Manajemen Keuangan (financial management) Buku Ajar.Akademi Keuangan \& Perbankan Riau (Akbar) Pekanbaru

Indra Priyanata (2017). Pengaruh Ukuran Perusahaan, Profitabilitas, dan Solvabilitas Terhadap Audit Delay, Skripsi Univesitas Pasundan, Bandung 2017. 
Kardinal SE, MM. (2016). Pengantar akuntansi. Modul Pembelajaran: Sekolah Tinggi Ilmu Ekonomi Multi Data Palembang

Kasmir. (2010). Analisis Laporan Keuangan. Jakarta: PT. Raja Grafindo Persada

Keputusan Menteri Tenaga Kerja dan Transmigrasi RI No. KEP-49/MEN/IV/2004

Kieso, Weygant, Warfield. (2018). Akuntansi Keuangan Menengah (Intermedieta Acoounting) Edisi IFRS Volume 2. Jakarta: Salemba Empat 2018.

Leidy Widjayanti. (2017). Analisa pengaruh laba bersih terhadap modal saham yang terdaftar di BEI. Jurnal Universitas Atma Jaya.

Lusi Heriyani \& Nurma Risa. (2015). Faktor yang mempengaruhi deviden kas. JRAK. Vol.6 No.2 Agusuts 2015

M. Riskiansyah. (2017). Pengaruh Upah Karyawan Terhadap Kinerja Karyawan Bagian Lapangan Pada Toko Classic Dalam Perspektif Islam. Skripsi UIN Raden Fatah Palembang.

Mainul, Roziq dan Sulistyo (2018). Influence Policy Liabilities, Size,Growth Corporate and Profitability and Value of the Company in the Agricultural Sector in Indonesia. Research Journal of Finance Accounting www.iiste.org ISSN 2222-1697 (Paper) ISSN 2222-2847 (Online) Vol.9, No.2, 2018

Masril. (2018). Pengaruh Car, Dar, Total Asset Terhadap Laba Bersih Pada Makanan Dan Minuman 2012-2016, Jurnal Wira Ekonomi Mikroskil Volume 8, Nomor 01, April 2018

Mulianti, Fitri Mega. (2010). Analisis Faktor-Faktor yang Mempengaruhi Kebijakan Hutang dan Pengaruhnya Terhadap Nilai Perusahaan. Tesis, Universitas Diponegoro

Nazahah (2017). Pengaruh Total Utang Dan Modal Kerja Terhadap Laba Bersih (Survei Pada Perusahaan Sektor Pertambangan Yang Terdaftar Di Bursa Efek Indonesia Periode 2010-2015) Skripsi, UniversitasKomputer Indonesia.

Nugraha, Susilo \& Aini. (2018). Pengaruh Human Capital Terhadap Kinerja Perusahaan (Studi pada Perusahaan Advertising dan Periklanan Malang yang Terdaftar pada Asosiasi Advertising dan Periklanan Malang). Jurnal Administrasi Bisnis (JAB)|Vol. 57 No. 2 April 2018

Ozcan Isik, Esra Aydin Unal, Yener Unal. (2017). The Effect Of Firm Size On Profitability: Evidence From Turkish Manufacturing Sector. Journal of Business, Economics and Finance (JBEF), ISSN: 2146-7943.

Pradana \& Azizah. (2018). Dampak Penerapan Akuntansi Sumber Daya Manusia Terhadap Kinerja Keuangan (Studi Pada PT. Perkebunan Nusantara X). Jurnal Administrasi Bisnis (JAB)|Vol. 62 No. 1 September 2018

Pramuna, Rahardja. (2013). Dampak Pengungkapan Sumber Daya Manusia Terhadap Reputasi Perusahaan. Diponegoro Journal Of Accounting Volume 2, Nomor 3, Tahun 2013.

Sawitri Sekaredi. (2011). Pengaruh Corporate Governance Terhadap Kinerja Keuangan Perusahaan. Skripsi, Universitas Diponegoro.

Sinambela, Lijan Poltak. (2012). Kinerja Pegawai. Graha Ilmu: Yogyakarta

Siyoto, Sandu., \& Sodik, Ali. (2015). Dasar Metodelogi Penelitian. Yogyakarta: Literasi Media Publishing

Sudana, Made. I. (2011). Manajemen Keuangan Perusahaan. Jakarta: Erlangga.

Sukmawati Mukhlis. (2017). Analisis Pengaruh Total Aset Terhadap Proporsi Pendapatan Operasional Selain Bunga Dengan Ldr (Loan To Deposit Ratio) Sebagai Variabel Moderating Pada Industri Perbankan Di Indonesia. Jurnal: Jurnal Ekonomi dan Bisnis, Vol. 7 No. 1 September 2017 ISSN: 2503-4413, Hal 1 - 12

Suliyanto. (2009). Metode Riset Bisnis, Penerbit Andi, Yogyakarta 
Susiartati. (2018). Pengaruh Total Hutang dan Besarnya Modal Sendiri Terhadap perolehan earning per share pada PT. BFI Finance yang Terdaftar di Bursa Efek Indonesia (BEI) Periode 2007-2016. Jurnal Manajemen dan Sains (JMAS) Vol.3 No.1, April 2018

Susiawan dan Muhid. (2009). Kepemimpinan Transformasional, Kepuasan Kerja dan Komitmen Organisasi, Persona, Jurnal Psikologi Indonesia September 2015, Vol.4, No.03, hal304-313

Syaiful, Nur Azizah. (2014). Pengaruh Free Cash Flow, Kepemilikan Manajerial, Kepemilikan Institusional dan Ukuran Perusahaan Terhadap Kebijakan Hutang pada Perusahaan Manufaktur Yang Terdaftar di Bursa Efek Indonesia (BEI). Skripsi, Universitas Negeri Medan.

Undang-Undang Ketenagakerjaan No.13/2003 ("UU 13/2003”).

Undang-undang Republik Indonesia No. 11 Tahun 1992

Undang-undang Republik Indonesia No. 11 Tahun 1992 tentang Dana Pensiun Bab I Pasal 1.

Vera handayani, Mayasari. (2018). Analisis Pengaruh Hutang Terhadap Laba Bersih Pada Pt. Kereta Api Indonesia (Persero). Jurnal Riset Akuntansi \& Bisnis Vol. 18 No. 1, Maret 2018, ISSN : 1693-7597

Waheed Husain. (2012). Corporations, Profit Maximization And The Personal Sphere.Economics and Philosophy / Volume 28 / Issue 03 / November 2012, pp 311 331 DOI: $10.1017 / \mathrm{S} 0266267112000260$

Website : https://www.Idx.co.id

Widiyanti, Airlangga. (2017). Pengungkapan Sumber Daya Manusia Dan Pengaruhnya Terhadap Citra Perusahaan. Prosiding Seminar Nasional dan Call For Paper Ekonomi dan Bisnis (SNAPER-EBIS 2017) - Jember, 27-28 Oktober 2017 (hal 426-433) ISBN : 978-602-5617-01-0

Zahara, Zannati. (2018). Pengaruh Total Hutang, Modal Kerja, Dan Penjualan Terhadap Laba Bersih Pada Perusahaan Sub Sektor Batu Bara Terdaftar Di Bei. Jurnal Riset Manajemen dan Bisnis (JRMB) Fakultas Ekonomi UNIAT Vol.3, No.2 Juni 2018: 155 164 P-ISSN 2527-7502 